\title{
Metagenomic analysis of Fusarium oxysporum f.sp. cubense-infected soil in banana plantation, Sukabumi, Indonesia
}

\author{
YUNUS EFFENDI ${ }^{1, \vartheta}$, A. PAMBUDI ${ }^{1}$, A. PANCORO $^{2}$ \\ ${ }^{1}$ Department of Biology, Universitas Al Azhar Indonesia. Jl. Sisingamangaraja No. 2, Jakarta Selatan 12110, Jakarta, Indonesia. \\ Tel.: +62-21-72792753, •email: effendiy@uai.ac.id \\ ${ }^{2}$ School of Life Science and Technology, Institut Teknologi Bandung. Labtek XI, Jl. Ganeca No.10, Bandung City 40132, West Java, Indonesia
}

Manuscript received: 19 March 2019. Revision accepted: 25 June 2019

\begin{abstract}
Effendi Y, Pambudi A, Pancoro A. 2019. Metagenomic analysis of Fusarium oxysporum $f$.sp. cubense-infected soil in banana plantation, Sukabumi, Indonesia. Biodiversitas 20: 1939-1945. Fusarium wilt is one of the most devastating diseases in banana plantation which caused by soil-borne fungal pathogen Fusarium oxysporum f.sp. cubense. In this study, metagenomic analysis of 16SrRNA gene was performed for comparing composition, richness, and abundance of healthy soils and Fusarium oxysporum f.sp. cubense (Foc)-infected soil microbes in rhizospheral area of banana plants. Data showed about 10969 OTU and 10755 OTU of bacteria were identified in healthy soils and Foc-infected soils respectively. The Foc-infected soils showed higher species abundance than healthy soil (ACE index 73,6 and 68,8 respectively). However, healthy soils have more taxa richness than infected-soil (Fisher index 447,7 and 343,4 respectively). Beta diversity analysis indicated infected-soils had lower bacterial diversity in comparison with healthy soils. About 37 phyla were identified and no statistical difference between both soil conditions in the OTUs abundance. However, Acidobacteria (22\%) and Verrucomicrobia (13\%) tend more abundance in the health soils in comparison in the infected soils $19 \%$ and $10 \%$ respectively, whereas Proteobacteria was found more abundance in the infected soil (11\%) in comparison with the health soil (7\%). Interestingly, high abundance of Xanthomonadaceae, member of Proteobacteria was identified in the infected soils which might have a positive correlation with incidence of Fusarium development in the soils.
\end{abstract}

Keywords: Banana, Fusarium oxysporum f.sp cubense, metagenomic, rhizospheral microbes

\section{INTRODUCTION}

Banana is one of the most widely grown fruit along tropic and sub-tropics. Due to its high health benefit and nutrient contains, Banana is the most popular fruit which consumes many people and widely grown in the world (FAO 2018). Banana is also popular fruit and widely consumed in Indonesia. Mostly banana production is done by smallholders in almost area in Indonesia, although there are also present some Banana estates Sumatra and Java islands. Banana production in Indonesia are mostly found in Java (54\%) and contributing to $68 \%$ of national banana production. However, large potential lands of banana plantation are available in Sumatera (over 1 million ha), Kalimantan, Sulawesi and Papua (over 3 million ha) (Djohar et al. 1999). Unfortunately national production of Banana showed decreasing since 1990s (Nurhadi et al, 1994). Pests and diseases contributed mainly in production decreasing and a limiting factor of banana production worldwide including in Indonesia (Getha et al. 2002; FAO 2015).

From many banana diseases have been identified worldwide, Fusarium wilt of banana which is known as Panama disease, is the most devastating banana disease in the world. This disease is caused by pathogenic soil-borne fungi, Fusarium oxysporum, which is commonly colonizing in vascular tissues of Banana and prevent transportation of water and nutrient in the pseudostem of infected banana. Thus, the plants are getting wilt which observed in yellowish leaves and later wilt totally on all leaves (Dita et al. 2010). Fusarium oxysporum f.sp cubense subgroup 'Tropical Race 4' (Foc TR4) is the most devastating race of Foc was recognized 1990s and had been identified as cause of serious losses of Cavendish banana in some areas of Southeast Asia (Ploetz and Churchill 2011).

Currently, no effective methods have been applied for avoiding Foc spreading. Few methods have been reported applied in some areas, but mostly has less effective impact not only economically but also less environmentally safe (Lin et al. 2016). Timely eradication of Foc-infected banana and avoiding Foc-contaminated soil are less methods which are applied in industrial banana plantation, although economically the methods are not applicable. A Foc-infected soil is difficult to be eradicated since Foc able to produce thick-cell wall chlamydospores, making it resistant to fungicides and fumigates (Shi et al. 1991). The spores of Foc can survive for long period under unsuitable soil condition for more than 30 years (Ploetz 2006; Ghag et al. 2015) and beginning actively infect banana root during banana plantation (O’Donnell et al. 1998).

During its life, plant develops important processes that necessary for its life. One of important processes is interaction with rhizosphere microbiome nearby plant root areas include bacteria, fungi, nematodes, protozoa, algae, and microarthropods (Raaijmakers et al. 2001). These microbiomes play important roles in ecological fitness of plants which interact with the microbiomes (Kent and 
Triplett 2002). Plant-microbe interactions may be considered beneficial, neutral, or harmful to the plant, depending on the specific microorganisms and plants involved and on the prevailing environmental conditions (Bais et al. 2006). In general, diversity of microbiomes in the soil is an important factor that has significant impacts on plant growth and development. However, to what level specificity of microbiomes especially bacteria, will contribute to plant-microbe interactions is remain unclear.

Most of bacteria in soils are unculturable (Nihorimbere et al. 2011) and using standard culturing techniques, less than $1 \%$ of bacterial diversity in most environmental samples was accounted (Amann et al. 1995). In other side, it well understands that knowing microbial diversity and their functional role in rhizosphere areas of plants is important information for understanding the role of bacteria and other microbes for plant growth. Metagenomic is a molecular-ecology based technique which provides a high throughput method for analyzing collective genome of bacterial and other microbial from environmental samples without providing standard cultivation (Ravin et al. 2015). Metagenomic analysis is initially performed by extracting of total DNA from samples (soil, water, food, etc) and followed by constructing of genomic library. Using high throughput sequencing technique (Next Generation Sequencing/NGS), specific conserved genes or genomic fragments such as $16 \mathrm{~S}$ rRNA, $18 \mathrm{~S}$ rRNA or Internal Transcribed Spacer (ITS) were sequenced and analyzed for diversity, abundance, phylogenetic and functional analysis of the all microbes that identified in the samples (Riesenfeld et al. 2004; Ghosh et al. 2019). Since the technique analyzes the entire presented DNA from the sample, thus all microbes (cultured and uncultured microbes) are counted.

In this study, analysis of soil bacterial diversity from banana plantation in Sukabumi, West Java-Indonesia was performed. Metagenomic analysis was performed by sequencing 16srRNA gene using NGS Illumina platform. Comparison of diversity, richness, and abundance of soil bacteria between Foc-infected soils and Foc-uninfected soils were done.

\section{MATERIALS AND METHODS}

\section{Sampling}

Soil samples were collected from Banana plantation of PTPN VIII in Parakan Salak Sukabumi, West Java, Indonesia with map coordinate $6^{\circ} 49^{\prime} 42.2^{\prime \prime S} 106^{\circ} 44^{\prime} 40.3^{\prime \prime E}$. Four soils samples were collected from 2 different sites. Two samples were collected from Foc-uninfected soil, whereas two other samples were collected from Focinfected soils (Figure1). Each sample consisted of $500 \mathrm{~g}$ soil samples which collected from 3 different sites nearby rhizosphere areas of infected or uninfected banana plants. The soil mixes were then homogenized and took $100 \mathrm{~g}$. The soil samples were kept in $-4^{\circ} \mathrm{C}$ until used.

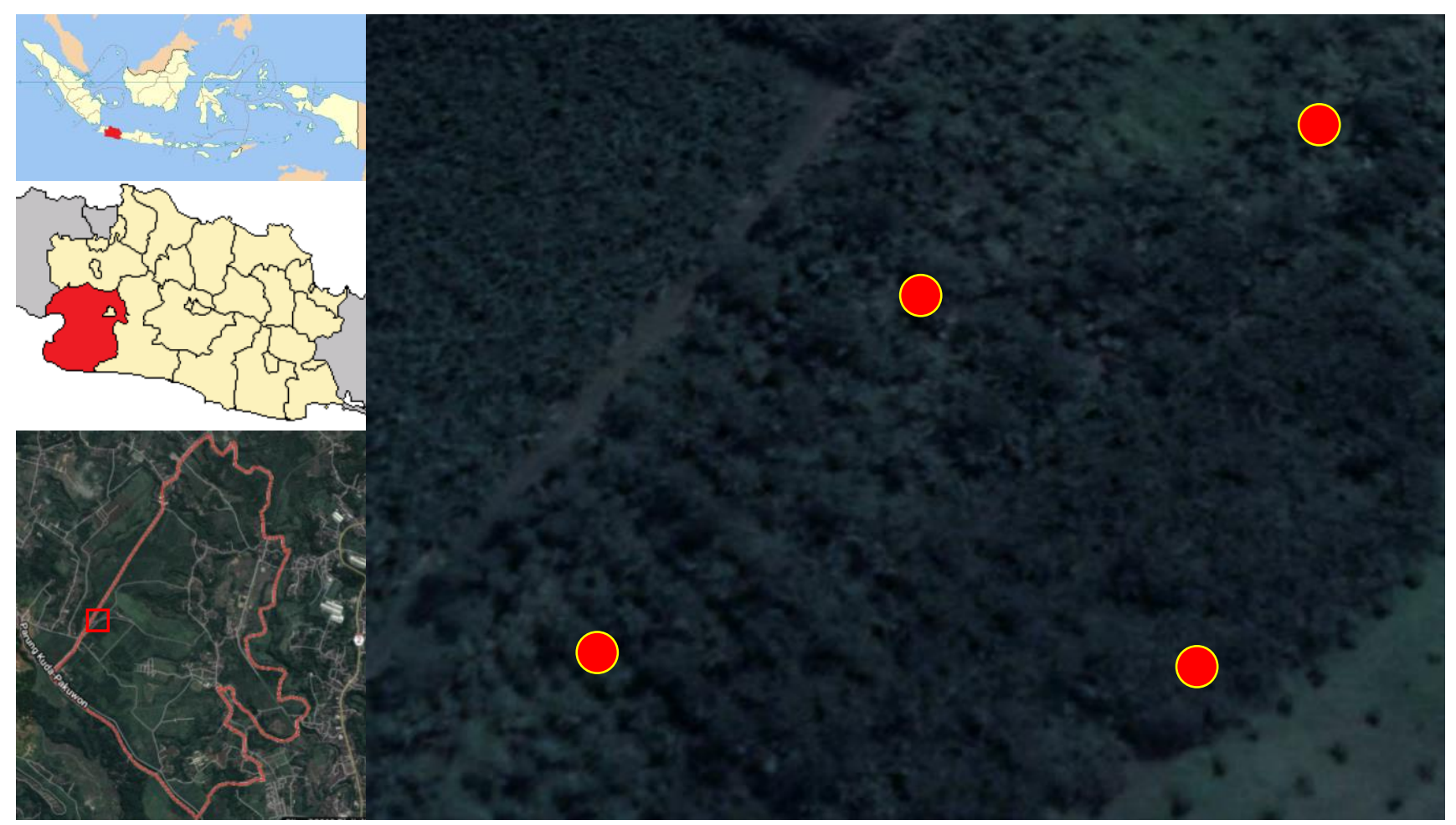

Figure 1. Sampling location is located in banana plantation of PTPN VIII-Parakansalak, Sukabumi, West Java, Indonesia. Samples were collected from 2 different soil conditions (Foc-infected and healthy soils), from each soil conditions were taken two independently soil samples (O) 


\section{DNA extraction and molecular works}

Whole genomic DNA was extracted using PowerSoil DNA kit (MoBio). DNA extraction was done following manual procedure of the kit. A $0.25 \mathrm{gr}$ soil of each sample were used as source of the genomic DNA. All procedures were performed aseptically for avoiding contamination. The DNA results were quantified using NanoDrop and checked its quality using gel electrophoresis. The DNA was used as template for PCR. A $2 \mu \mathrm{L}$ of DNA was added to $10 \mu \mathrm{L}$ PCR mix (GoTaq ${ }^{\circledR}$ Green Master mix-PROMEGA) and $1 \mathrm{nmol}$ of each forward and reverse 16srRNA primer. Reaction was performed 35 cycles which consisted of 30 sec at $94^{\circ} \mathrm{C}$ and continued with $57^{\circ} \mathrm{C}$ of annealing for 20 sec, followed with $2 \mathrm{~min} 72^{\circ} \mathrm{C}$ for elongation.

A region V4 of 16srRNA gene was amplified with primer F515 (5'-GTGCCAGCMGCCGCGGTAA-'3) and 907R (5'-CCGTCAATTCMTTTRAGTTT-'3) (Lane 1991). The PCR products were purified and subjected for automated Illumina Miseq platform ( $1^{\text {st }}$ BASE-Malaysia) after the PCR products were normalized in equimolar amounts.

\section{Sequences analysis}

Raw sequence data generated from Illumina Miseq platform were processed in QIIME Ver 6.0 (Caporaso et al. 2010). All sequences are shorter than 150 bp or longer than $600 \mathrm{bp}$ are removed from downstream processing. Read were then aligned with 16srRNA SILVA database (www.arb-silva.de) and GRD database (metasystems.riken.jp/grd/), then followed inspected for chimeric errors. "Species-level" of OUT was used in analysis, thus reads then were clustered at $97 \%$ similarity into OTUs. In this step, rare OTUs with only 1 (singleton) or 2 reads (doubleton) are deleted from downstream processing. Taxonomic assignment was carried out with the RDP Classifier (Wang et al. 2007).

\section{Data analysis}

Alpha and Beta diversity analysis were performed using Explicet ver 2.10.5 software (Robertson et al. 2013). Statistical comparison of alpha diversity between samples was carried out with Excel (Microsoft) whereas statistically different $(P$-value $)$ was calculated with T-test. Samplespecific OTUs (showing significantly different relative abundances between samples) were assessed by T-test. Heat map which showed relative abundances between samples in certain taxa level was generated with Explicet ver 2.10 .5 software. Venn diagrams were made to visualize which OTUs were shared between infected and healthy soils using Explicet ver 2.10.5 software.

\section{RESULT AND DISCUSSION}

\section{Structure and diversity of soil bacteria}

A total of 37,909,152 reads was obtained using Illumina Miseq sequencing of 16rrRNA gene. Of it total of $35,149,668$ reads $(87.5 \%)$ passed filter. After primer removal and length-and quality filtering, followed with removal of singleton as well as doubletons, about 20.000 reads for each sample were obtained. These reads have passed quality filtering control (mean of read length and GC\%). "Species-level" of OUT was used in analysis, thus reads were clustered at $97 \%$ similarity into OTUs. About 9.000-11.000 OTUs were identified for each sample (Table 1).

Bacterial community analyses showed that the infected soils had relative higher of species richness and had more species abundance than the health soils. Nevertheless, there was no significant differences in species richness between the infected soils and the health soils. Alpha diversity analysis summarized that species diversity (richness) of health soils was higher than infected soils, which showed on higher Simpson diversity index (7.5-7.7) and Fisher alpha indexes (379.4-516.1). The richness index of the Chao1 estimator (Chao1) (Chao 1984) and the abundancebased Coverage estimator (ACE) (Eckburg et al. 2005) was calculated to estimate the number of observed OTUs that were present in the sampling assemblage. The diversity within each individual sample was estimated using the nonparametric Shannon diversity index (Washington 1984).

The ACE estimator indicated that species abundance was observed relative higher in the infected soils than in the health soils, even Chaol index indicated only a slight difference of species abundance between these soils (Table 2).

Metagenomic analysis showed that bacteria dominate the diversity of microbiome in the soil samples (99\%) of both soil conditions. Archaea presented $0.04 \%$ and $0.012 \%$ in health soil and infected soil respectively. A total of 39 phyla were identified in the soil samples, however, the abundance of these phyla are statistically not different (Table 3).

Analysis of taxonomic abundance of species between the health and the infected soils showed varied diversity within samples. The abundance of major bacterial phylum was observed less different (Figure 2). From 11 major bacteria phylum which was compared, no significant difference between health soils and infected soils was found. However, some phyla tend to present more abundance in one of the soil conditions.

Table 1. Number of sequences and OTUs after filtering

\begin{tabular}{lccc}
\hline \multicolumn{1}{c}{ Group } & $\begin{array}{c}\text { Screen }<\mathbf{1 5 0} \\
\text { bp and }>\mathbf{6 0 0} \\
\text { bp }\end{array}$ & $\begin{array}{c}\text { Chimera, } \\
\text { singleton, and } \\
\text { doubletons } \\
\text { removal }\end{array}$ & $\begin{array}{c}\text { Number } \\
\text { of OTUs }\end{array}$ \\
\hline Health soil1 & 244147 & 118229 & 11364 \\
Health soil2 & 213990 & 105205 & 9630 \\
Infected soil1 & 205317 & 91449 & 10575 \\
Infected soil2 & 247097 & 109523 & 11880 \\
\hline
\end{tabular}

Tabel 2. Diversity and richness indexes

\begin{tabular}{llllll}
\hline Group & Chao1 & ACE & Shannon & Simpson & Fisher \\
\hline Infected soils1 & 9956 & 79.33211 & 48.0574 & 7.798442 & 504.8816 \\
Infected soils2 & 8278 & 67.98454 & 42.94576 & 7.239521 & 181.9179 \\
Health soils1 & 9300 & 63.20111 & 43.50184 & 7.773869 & 516.0863 \\
Health soils2 & 9469 & 74.49042 & 46.99294 & 7.540323 & 379.3965 \\
\hline
\end{tabular}


Table 3. Abundance of taxonomic phyla groups health and infected soils

\begin{tabular}{|c|c|c|c|}
\hline Phylum & Health soil & Infected soil & p-value \\
\hline \multicolumn{4}{|l|}{ Archaea } \\
\hline Crenarchaeota & $0.00033 \pm 0.00006$ & $0.00017 \pm 0.00004$ & 0.27 \\
\hline Euryarchaeota & $0.00003 \pm 0.00002$ & $0.00026 \pm 0.00020$ & 0.07 \\
\hline Parvarchaeota. & $0.00005 \pm 0.00005$ & $0.00000 \pm 0.00000$ & 0.26 \\
\hline \multicolumn{4}{|l|}{ Bacteria } \\
\hline$A D 3$ & $0.05517 \pm 0.02247$ & $0.08320 \pm 0.01472$ & 0.41 \\
\hline Acidobacteria & $0.20938 \pm 0.01099$ & $0.17915 \pm 0.00467$ & 0.06 \\
\hline Actinobacteria & $0.02296 \pm 0.00359$ & $0.02922 \pm 0.00246$ & 0.31 \\
\hline Armatimonadetes & $0.00410 \pm 0.00054$ & $0.00356 \pm 0.00041$ & 0.42 \\
\hline BHI80.139 & $0.00010 \pm 0.00003$ & $0.00009 \pm 0.00002$ & 0.17 \\
\hline$B R C l$ & $0.00025 \pm 0.00025$ & $0.00020 \pm 0.00020$ & 0.56 \\
\hline Bacteroidetes & $0.00789 \pm 0.00019$ & $0.00232 \pm 0.00192$ & 0.07 \\
\hline Chlamydiae & $0.00094 \pm 0.00047$ & $0.00102 \pm 0.00053$ & 0.33 \\
\hline Chlorobi & $0.00012 \pm 0.00001$ & $0.00056 \pm 0.00044$ & 0.11 \\
\hline Chloroflexi & $0.21542 \pm 0.02283$ & $0.20454 \pm 0.01260$ & 0.46 \\
\hline Cyanobacteria & $0.00129 \pm 0.00004$ & $0.00194 \pm 0.00054$ & 0.11 \\
\hline Elusimicrobia & $0.00197 \pm 0.00028$ & $0.00144 \pm 0.00011$ & 0.25 \\
\hline$F B P$ & $0.00000 \pm 0.00000$ & $0.00001 \pm 0.00001$ & 0.21 \\
\hline FCPU426 & $0.00282 \pm 0.00067$ & $0.00212 \pm 0.00015$ & 0.51 \\
\hline Fibrobacteres & $0.00014 \pm 0.00004$ & $0.00042 \pm 0.00031$ & 0.23 \\
\hline Firmicutes & $0.00054 \pm 0.00032$ & $0.00054 \pm 0.00012$ & 0.24 \\
\hline GAL15 & $0.00716 \pm 0.00309$ & $0.01918 \pm 0.00502$ & 0.09 \\
\hline GNO2 & $0.00001 \pm 0.00001$ & $0.00001 \pm 0.00001$ & 0.22 \\
\hline Gemmatimonadetes & $0.00942 \pm 0.00192$ & $0.00976 \pm 0.00069$ & 0.31 \\
\hline Kazan.3B.28 & $0.00004 \pm 0.00004$ & 0.000000 .00000 & 0.34 \\
\hline $\mathrm{NClO}$ & $0.00000 \pm 0.00000$ & $0.00003 \pm 0.00003$ & 0.44 \\
\hline NKB19 & $0.00124 \pm 0.00123$ & $0.00058 \pm 0.00058$ & 0.43 \\
\hline Nitrospirae & $0.01218 \pm 0.00175$ & $0.01494 \pm 0.00217$ & 0.12 \\
\hline$O D 1$ & $0.00004 \pm 0.00004$ & $0.00000 \pm 0.00000$ & 0.24 \\
\hline OP11 & $0.00000 \pm 0.00000$ & $0.00003 \pm 0.00003$ & 0.32 \\
\hline OP3 & $0.00124 \pm 0.00123$ & $0.00058 \pm 0.00058$ & 0.09 \\
\hline Planctomycetes & $0.01218 \pm 0.00175$ & $0.01494 \pm 0.00217$ & 0.33 \\
\hline Proteobacteria & $0.02411 \pm 0.00601$ & $0.02245 \pm 0.00378$ & 0.15 \\
\hline Synergistetes & $0.00000 \pm 0.00000$ & $0.00002 \pm 0.00002$ & 0.23 \\
\hline TM6 & $0.00118 \pm 0.00092$ & $0.00044 \pm 0.00025$ & 0.15 \\
\hline$T M 7$ & $0.16714 \pm 0.01058$ & $0.00820 \pm 0.00639$ & 0.37 \\
\hline Verrucomicrobia & $0.06428 \pm 0.00510$ & $0.10006 \pm 0.02639$ & 0.31 \\
\hline WPS. 2 & $0.00004 \pm 0.00004$ & $0.00012 \pm 0.00009$ & 0.25 \\
\hline WS3 & $0.00292 \pm 0.00269$ & $0.00007 \pm 0.00002$ & 0.24 \\
\hline Thermi & $0.00294 \pm 0.00049$ & $0.00820 \pm 0.00639$ & 0.16 \\
\hline
\end{tabular}

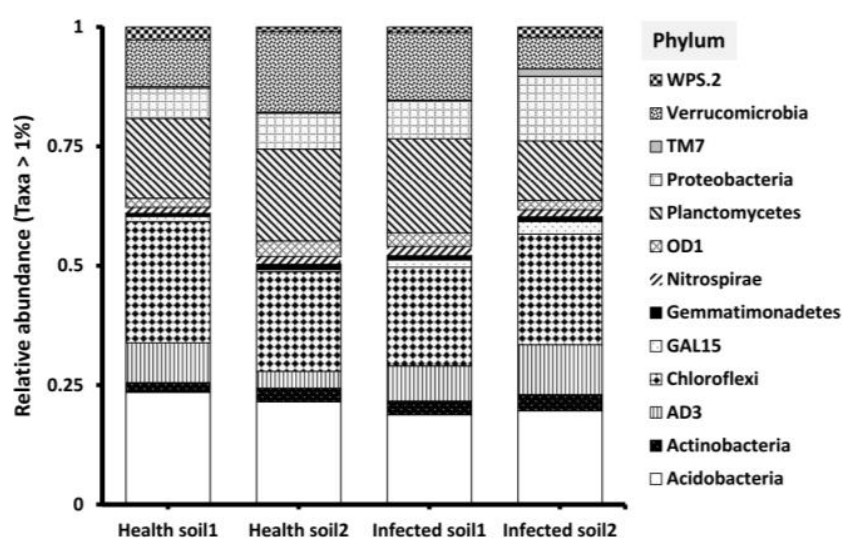

Figure 2. Relative abundance of phylum taxa in health- and Focinfected soils.

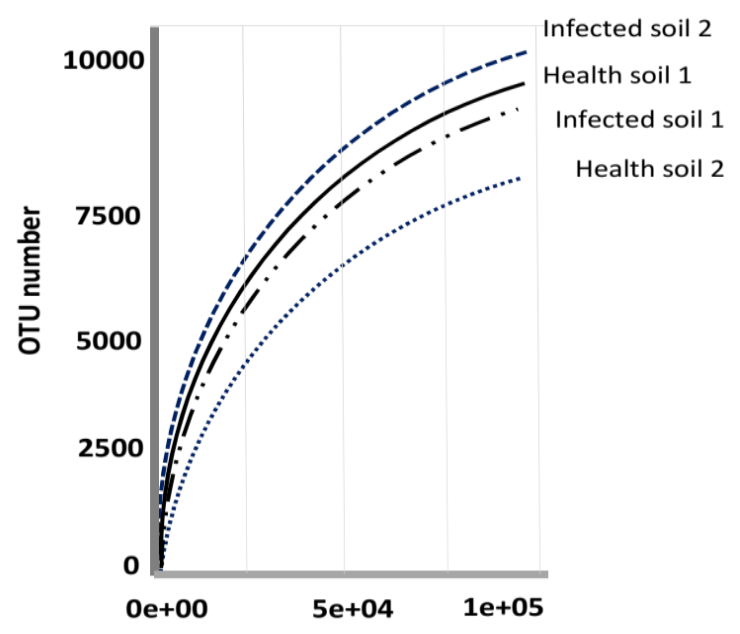

Figure 4. Rarefaction curve of all soil samples. Data showed number of OTUs abundance of each soil condition

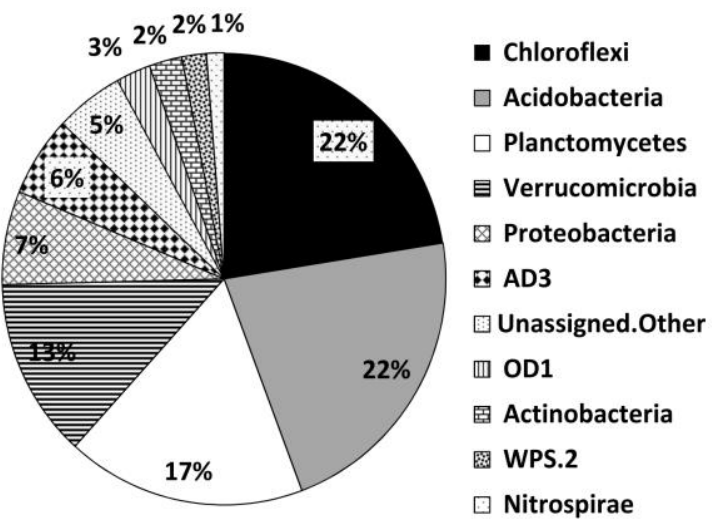

A

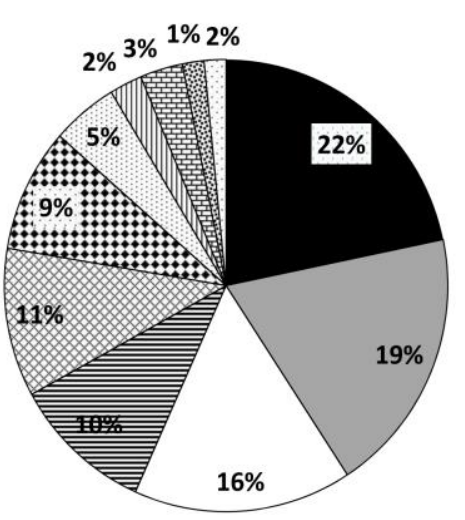

B

Figure 3. Relative abundance of major phyla taxa of both soil conditions. a) Relative abundance of phyla in health soils indicated that Acidobacteria and Verrucomicrobia were higher than in infected soil, b) Relative abundance of phyla in infected soils, Proteobacteria had more abundance in comparison to health soil. 


\section{Relationship between soil conditions and microbial abundances}

Acidobacteria $(22 \%)(P<0.06)$ and Verrucomicrobia $(13 \%)(P<0.31)$ were more abundant in the health soils in comparison in the infected soils $19 \%$ and $10 \%$ respectively, whereas Proteobacteria was found more in the infected soil $(11 \%)(P<15)$ in comparison with the health soil $(7 \%)$ (Figure 3).

Nevertheless, there were no significant differences in the relative abundances of these dominant species in both soil conditions. Rarefaction curve confirmed the data that number of OTUs is varied abundance in range from 936011880 OTUs in the soil samples (Figure 4). Proteobacteria was found higher in infected soil than in health soils. The more abundance of Proteobacteria in infected soils in this study was suggested as one of important factors which composed a suitable environment for pathogenic microbes growing. Sanguin et al. (2009) reported Proteobacteria abundance was negatively correlated with disease suppression.

The relatively high abundance of Acidobacteria in both soils in our study might correspond with acid soil condition ( $\mathrm{pH}$ 4.9-5.1). In addition, the data showed that the Acidobacteria was found relative higher $(22 \%)$ in the health soils than in the infected soil $(19 \%)$. Whether it contributed to incidence of higher number of Foc in the soils or not, it remained a hypothesis. Soil pH strongly influences the composition of soil microbial community. Soil acidity is linked to the decrease of available carbon for soil microbes (Wang et al. 2007), thus acidity of soil will contribute significantly diversity of soil microbes. Indeed, several study of a bio-organic fertilizer (BIO) application to various orchard with serious Fusarium wilt disease showed effectively enhancing suppression of Fusarium wilt disease by ameliorating structure of the microbial community (Cotxarrera et al. 2002; Kavino et al. 2010; Zhao et al. 2011; Shen et al. 2013). Shen et al. (2014) showed that BIO-treated soil effectively decreased the number of soil Fusarium sp. and controlled the soil-borne disease. Correlation analysis indicated that there was a significant correlation between the abundance of Gemmatimonadetes $(\mathrm{r}=-0.579, \mathrm{p}=0.024)$ and Bacteroidetes $(\mathrm{r}=0.600$, $\mathrm{p}=0.018$ ) phyla and Fusarium wilt disease incidence (Shen et al. 2014). Shen et al. result are more or less similar to our data. Our data showed infected soils have slightly lower abundance of Gemmatimodetes $(0.947 \%)$ and higher abundance of Bacteroidetes $(0.732 \%)$, whereas health soils have $0.972 \%$ and $0.289 \%$ respectively. Statistical analysis indicated Bacteroidetes phylum showed a slightly different in abundance (P-value > 0.07) (Tabel 2). In a high abundance, the Bacteroidetes has positive corresponding to initial and disease stage of Fusarium wilt disease incidence whereas decreasing of the Fusarium disease incidence was significantly shown when suppressiveness of this phyla was reached (Kyselková et al. 2009; Shen et al. 2014).

Moreover, significantly different in abundance of Sphingomonas genus which 3.4 time more frequently found in infected soils than in health soils is also consistent with Shen et al. (2014). On their report, Shen et al. (2014) described a strong negative correlation between Fusarium wilt disease incidence and Gemmatimonas ( $\mathrm{r}=-0.579$, $\mathrm{p}=0.024)$ and Sphingomonas $(\mathrm{r}=-0.689, \quad \mathrm{p}=0.005)$ abundance. Indeed, Gemmatimonas and Sphingomonas genus were found frequently in the Fusarium wilt disease infected soils than in the health soils (Shen et al. 2014).

The composition of the soil microbial community and induced changes caused by its amendment, provide useful information on soil health and quality (Poulsen et al. 2013). Maintaining biodiversity of soil microbes is crucial to soil health because a decrease in soil microbial diversity is responsible for the development of soil-borne diseases (Mazzola 2004). Determining the responses of soil bacterial communities to different organic amendments is particularly important because the bacterial community is one of the main components that determine soil health and is believed to be one of the main drivers in disease suppression (Garbeva et al. 2004).

Naturally, suppressive soil condition on certain pathogenic microbes relies on at least two important factors, first a general mechanism of competition for nutrients caused by the whole soil microflora and the second a specific competition between pathogenic and nonpathogenic microbes strains. Composition and diversity of microflora at the end will determine whether certain pathogenic microbes dominate the soil or not.

The abundance of Proteobacteria members on healthiness banana plants has been reported in several studies (Shen 2014; Köberl et al. 2017). Comparative microbiome analyses between healthy and diseased Gros Michel plants on Fusarium Wilt-infested farms in Nicaragua and Costa Rica revealed significant shifts in the gammaproteobacterial microbiome (Köberl et al. 2017). The Author found diversity and community members of Gammaproteobacterial were identified as potential health indicators. Indeed, increasing of plant-beneficial Pseudomonas and Stenotrophomonas correlated positively with healthy plants (Köberl et al. 2017).

In contrast with our study, the abundance Xantomonadaceae family, one of Proteobacteria phyla member was found relatively higher in infected soils than in health soils (Figure 5). The family of Xantomonadaceae has been known well as one of the pathogenic family which caused Banana Xanthomonas Wilt (BXW) (Biruma et al. 2007). However, Köberl et al. (2017) reported that Xantomonadaceae presented in higher number in healthy plants. In other studies, Proteobacteria abundance was identified negatively correlated with Fusarium disease suppression thus confirming that the outbreak stage of wheat take-all disease is mainly attributed to the prevalence of Proteobacteria (Sanguin et al. 2009). It may be concluded Proteobacteria might present as positive or negative factors on the development of pathogenic bacteria in the soil is dependent on which specific bacterial taxa dominate in the soil (Biruma et al. 2007; Shen et al. 2015; Köberl et al. 2017). 


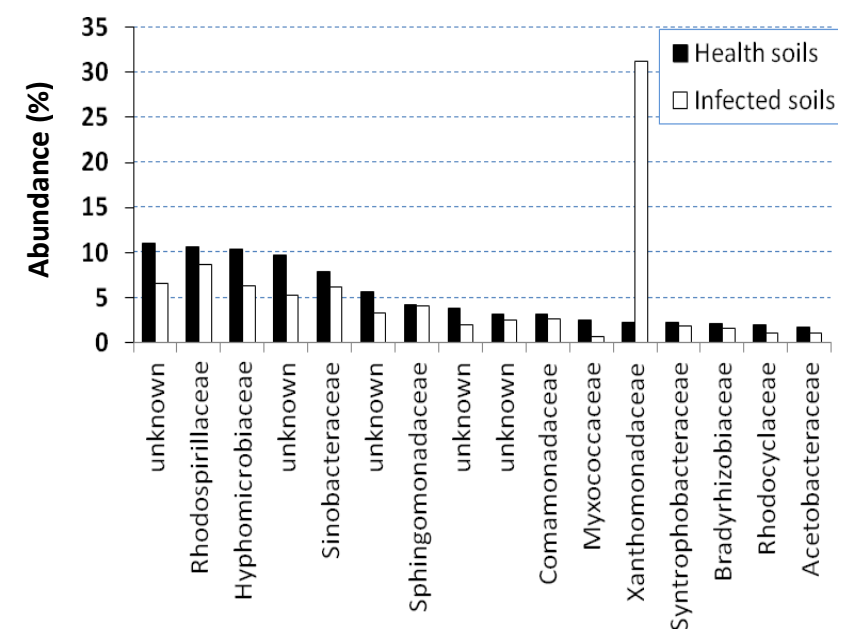

Figure 5. Top 16 families belong Proteobacteria which identified in healths and infected soils. Xanthomonadaceae showed more abundance in infected soils than in health soils $(P$-value $>0.07)$

In our data, the abundance of various genus members of Proteobacteria phyla which commonly are known as plant disease-caused bacteria (Peeters et al. 2013; Safni et al. 2018) was also found more in the infected soils than in healthy soils. Ralstonia genus present 5 times more frequently in infected-soils than in healthy soils. But we found some beneficial genus members of Proteobacteria phyla were also higher abundance in infected soils than in health soils (Azospirillum-free-living aerobic nitrogen fixer, Rhodanobacter-denitrifying bacteria). Those indicated Proteobacteria was not a proper phylum for indicating healthiness of soils.

In conclusion, the result from the present study demonstrated that composition, diversity, and richness of microbiome in rhizospheral areas of banana plants in banana plantation Sukabumi might correspond with the incidence of Fusarium development in the rhizosphere soils. The more abundances of bacteria belong to Acidobacteria and Verrucomicrobia phyla might associate with the healthiness of the soils, whereas higher abundances of Proteobacteria, particularly Xanthomonadaceae family might contribute positively to Fusarium development in the soils.

\section{ACKNOWLEDGEMENTS}

This research had been supported financially by research grant of PTUPT 2018 from The Ministry of Research Technology and Higher Education-Republic of Indonesia.

\section{REFERENCES}

Amann RI, Ludwig W, Schleifer KH. 1995. Phylogenetic identification and in situ detection of individual microbial cells without cultivation. Microbiol Rev 59: 143-69.
Anonymous. 2003. Information on Horticulture and Various Crops. Directorate General Production of Horticulture and Various Plants, Jakarta. [Indonesian]

Bais HP, Weir TL, Perry LG, Gilroy S, Vivanco JM. 2006. The role of root exudates in rhizosphere interactions with plants and other organisms. Annu Rev Plant Biol 57: 233-266.

Biruma M, Pillay M, Tripathi L, Blomme G., Abele S, Mwangi M, Bandyopadhyay R, Muchunguzi P, Kassim S, Nyine M, Turyagyenda L, Eden-Green S. 2007. Banana Xanthomonas wilt: A review of the disease, management strategies and future research directions. Afr J Biotechnol 6(8): 953-962.

Caporaso JG, Kuczynski J, Stombaugh J, Bittinger K, Bushman FD, Costello EK, ... Huttley GA. 2010. QIIME allows analysis of highthroughput community sequencing data. Nat Methods 7(5): 335.

Chao A. 1984. Nonparametric estimation of the number of classes in a population. Scand J Stat 11: 265-270.

Cotxarrera L, Trillas-Gay MI, Steinberg C, Alabouvette C. 2002. Use of sewage sludge compost and Trichoderma asperellum isolates to suppress Fusarium wilt of tomato. Soil Biol Biochem 34: 467-476.

Dita MA, Waalwijk C, Buddenhagen IW, Souza MT, Kema GHJ. 2010. A molecular diagnostic for tropical race 4 of the banana Fusarium wilt pathogen. Plant Pathol 59: 348-357

Djohar H.H., Wahyunto, V. Suwandi, H. Subagjo. 1999. Peluang pengembangan lahan untuk komoditas pisang di Indonesia. Indonesian Agricultural Research and Development Journal 18(2)

Eckburg PB, Bik EM, Bernstein CN, Purdom E, Dethlefsen L, et al. 2005. Diversity of the human intestinal microbial flora. Science 308: 1635 1638.

FAO. 2015. FAO Yearbook (Production). Food and Agriculture Organization of the United Nations.

FAO. 2018. Banana market view 2017. Food and Agriculture Organization of the United Nations.

Garbeva P, Van VJ, Van EJ. 2004. Microbial diversity in soil: selection of microbial populations by plant and soil type and implications for disease suppressiveness. Annu Rev Phytopathol 42: 243-270.

Ghag SB, Shekhawat UKS, Ganapathi TR. 2015. Fusarium wilt of banana: biology, epidemiology and management. Int $\mathrm{J}$ Pest Manag 61: 250-263.

Ghosh A, Mehta A, Khan AM. 2019. Metagenomic Analysis and its Applications. Encyclopedia Bioinformatics Comput Biol 3: 184-193

Getha K, Vikineswary S. 2002. Antagonistic effects of Streptomyces violaceusniger strain $\mathrm{G} 10$ on Fusarium oxysporum f.sp. cubense race 4: indirect evidence for the role of antibiosis in the antagonistic process. J Ind Microbiol Biotechnol 28: 303-310.

Kavino M, Harish S, Kumar N, Saravanakumar D, Samiyappan R. 2010. Effect of chitinolytic PGPR on growth, yield and physiological attributes of banana (Musa spp.) under field conditions. Appl Soil Ecol 45: 71-77.

Kent AD, Triplett EW. 2002. Microbial communities and their interactions in soil and rhizosphere ecosystems. Ann Rev Microbiol 56: 211-236.

Köberl M, Dita M, Martinuz A, Staver C, Berg G. 2017. Members of Gammaproteobacteria as indicator species of healthy banana plants on Fusarium wilt-infested fields in Central America. Sci Rep 7: 45318.

Kyselková M, Kopecký J, Frapolli M, Défago G, Ságová-Marečková M, Grundmann GL, Moënne-Loccoz Y. 2009. Comparison of rhizobacterial community composition in soil suppressive or conducive to tobacco black root rot disease. ISME J 3(10): 1127.

Lane DJ. 1991. 16S/23S rRNA sequencing. In: Stackebrandt E, Goodfellow M (eds) Nucleic acid techniques in bacterial systematics. John Wiley and Sons, New York, pp. 115-175

Lin YH, Lin YJ, Chang TD, Hong LL, Chen TY, Chang PFL. 2016. Development of a TaqMan probe-based insulated isothermal polymerase chain reaction (iiPCR) assay for detection of Fusarium oxysporum f. sp. cubense race 4. PLoS ONE 11: e0159681. DOI: 10.1371/journal.pone.0141825

Mazzola M. 2004. Assessment and management of soil microbial community structure for disease suppression. Annu Rev Phytopathol 42: 35-59.

Nihorimbere V, Ongena M, Smargiassi M, Thonart P. 2011. Beneficial effect of the rhizosphere microbial community for plant growth and health. Biotechnol Agron Soc Environ 15: 327-337.

Nurhadi, Rais, M. and Harlion. 1994. Serangan bakteri dan cendawan pada tanamanpisang di Dati I. Lampung. Info Hort. 2(1):35-37

O'Donnell K, Kistler KC, Cigelnik E, Ploetz RC. 1998. Multiple evolutionary origins of the fungus causing Panama disease of banana: 
concordant evidence from nuclear and mitochondrial gene genealogies. Proc Natl Acad Sci USA 95: 2044-2049.

Peeters N, Guidot A, Vailleau F, Valls M. 2013. Ralstonia solanacearum a widespread bacterial plant pathogen in the post-genomic era. $\mathrm{Mol}$ Plant Pathol 14 (7): 651-62

Ploetz RC. 2006. Fusarium wilt of banana is caused by several pathogens referred to as Fusarium oxysporum f. sp. cubense. Phytopathology 96 653-656.

Ploetz RC, Churchill ACL. 2011. Fusarium Wilt: the Banana Disease that Refuses to Go Away. Proc Int ISHS-ProMusa Symp on Global Perspectives on Asian Challenges Eds.: I. Van den Bergh et al. Acta Hort 897: 519-526.

Poulsen PH, Al-Soud WA, Bergmark L, Magid J, Hansen LH, Sørensen SJ. 2013. Effects of fertilization with urban and agricultural organic wastes in a field trial-Prokaryotic diversity investigated by pyrosequencing. Soil Biol Biochem 57: 784-793.

Raaijmakers JM. 2001. Rhizosphere and rhizosphere competence. In: Maloy OC, Murray TD (eds) Encyclopedia of plant pathology. Wiley, USA.

Ravin NV, Mardanov AV, Skryabin KG. 2015. Metagenomics as a tool for the investigation of uncultured microorganisms. Russ J Genet 51 431-439.

Riesenfeld CS., Schloss PD, Handelsman J. 2004. METAGENOMICS Genomic Analysis of Microbial Communities. Annu Rev Genet 38 525-52.

Robertson CE, Harris JK, Wagner BD, Granger D, Browne K, Tatem B, Feazel LM, Park K, Pace NR, Frank DN. 2013. Explicet: graphical user interface software for metadata-driven management, analysis, and visualization of microbiome data. Bioinformatics 29 (23): 31003101 .
Safni I, Subandiyah S, Fegan M. 2018. Ecology, Epidemiology and Disease Management of Ralstonia syzygii in Indonesia. Front Microbiol 9: 419 .

Sanguin H, Sarniguet A, Gazengel K, Moënne-Loccoz Y, Grundmann G. 2009. Rhizosphere bacterial communities associated with disease suppressiveness stages of take-all decline in wheat monoculture. New Phytol 184: 694-707.

Shen Z, Wang D, Ruan Y, Xue C, Zhang, J, Li R, Shen Q. 2014. Deep 16S rRNA Pyrosequencing Reveals a Bacterial Community Associated with Banana Fusarium Wilt Disease Suppression Induced by Bio-Organic Fertilizer Application. PLoS One 9 (5): e98420. DOI: 10.1371/journal.pone.0098420.

Shen Z, Ruan Y, Chao X, Zhang J, Li R, She Q. 2015. Rhizosphere microbial community manipulated by 2 years of consecutive biofertilizer application associated with banana Fusarium wilt disease suppression. Biol Fertil Soils 51(5): 553-562.

Shen Z, Zhong S, Wang Y, Wang B, Mei X, Li R, Shen Q. 2013. Induced soil microbial suppression of banana fusarium wilt disease using compost and biofertilizers to improve yield and quality. Eur J Soil Biol 57: 1-8.

Shi J, Mueller WC, Beckman CH. 1991. Ultrastructural responses of vessel contact cells in cotton plants resistant or susceptible to infection by Fusarium oxysporum f. sp. vasinfectum. Physiol Mol Plant Pathol 38: 211-222.

Wang Q, Garrity GM, Tiedje JM, Cole JR. 2007. Naïve bayesianclassifier for rapid assignment of rRNA sequences into the new bacterial taxonomy. Appl Environ Microbiol 73: 5261-5267.

Washington HG. 1984. Diversity, biotic and similarity indices. Water Res 18: 653-694.

Zhao Q, Dong C, Yang X, Mei X, Ran W, Shen Q, Xu Y. 2011. Biocontrol of Fusarium wilt disease for Cucumis melo melon using bio-organic fertilizer. Appl Soil Ecol 47(1): 67-75 